\title{
PERBEDAAN CULTURE SHOCK DITINJAU DARI TIPE KEPRIBADIAN EXTROVERTDAN INTROVERT PADA MAHASISWA KARO UKSW ANGKATAN 2019 YANG BERASAL DARI SUMATERA UTARA
}

\author{
Yessy Sepgina Br Manik ${ }^{1 *}$, Berta Esti Ari Prasetya ${ }^{2}$ \\ Fakultas Psikologi, Universitas Kristen Satya Wacana, Salatiga, Indonesia ${ }^{1,2}$ \\ e-mail: yessymanik7@gmail.com
}

Received April 24, 2021; Revised Month DD, 2021; Accepted September 14, 2021 Published Online September 14,2021

\section{Conflict of Interest} Disclosures:

The authors declare that they have no significant competing financial, professional or personal interests that might have influenced the performance or presentation of the work described in this manuscript.
Abstract: Student's who choose to continue their education outside of their home region will learn to adjust to the new environtment, so that individuals who are unable to adapt will feel culture shock. The purpose of this study was to determine the differences in culture shock in terms of extrovert and introvert personality types in students, with the hypothesis that there are differences between extrovert and introvert individuals in dealing with culture shock. The research sample consisted of 50 Satya Wacana Christian University Karo student's who came from North Sumatera and used a total sampling technique. The measurement of this research was used Mumford's (1997) culture shock scale with $(r=0,822)$ and Eyesenck's extrovert and introvert personality scale, the Eyesenck Personality Questionnaire (EPQ) with $(r=0,847)$. Hypothesis analysis using the Mann Whitney U Test, which shows significant results with $p=0,000(p<0,05)$. Thus, individuals with an extrovert personality will have a lower level of culture shock, while individuals with an introverted personality will have a higherlevel of culture shock.

Keywords: Student, Culture shock, Extrovert and introvert personality.

Abstrak: Mahasiswa yang memilih untuk melanjutkan pendidikan di luar dari daerah asalnya akan belajar untuk menyesuiakan diri dengan lingkungan yang baru, sehingga individu yang tidak mampu menyesuaikan diri akan merasakan culture shock. Tujuan penelitian ini adalah untuk mengetahui perbedaan culture shock yang ditinjau dari tipe kepribadian extrovert dan introvert pada mahasiswa, dengan hipotesis terdapat perbedaan antara individu extrovert dan introvert dalam menghadapi culture shock. Sampel penelitian berjumlah 50 orang mahasiswa Karo Universitas Kristen Satya Wacana yang berasal dari Sumatera Utara dan menggunakan teknik total sampling. Pengukuran penelitian ini menggunakan skala culture shock milik Mumford (1997) dengan $(\mathrm{r}=0,822)$ dan skala kepribadian extrovert dan introvert milik Eyesenck yaitu Eyesenck Personality Questionnaire $(E P Q)$ dengan $\mathrm{r}=(0,847)$. Analisis hipotesis menggunakan Mann Whitney U Test, yang menunjukkan hasil signifikan dengan $\mathrm{p}=0,000 \quad(\mathrm{p}<0,05)$. Dengan demikian, Individu dengan kepribadian extrovert akan memiliki tingkat culture shock yang lebih rendah, sedangkan individu dengan kepribadian introvert akan memiliki tingkat culture shock yang lebih tinggi.

Kata Kunci: Mahasiswa, Culture shock, Kepribadian Extrovert dan Introvert.

How to Cite: Yessy Sepgina Br Manik, Berta Esti Ari Prasetya. 2021. Perbedaan Culture shock ditinjau dari tipe kepribadian extrovert dan introvert pada mahasiswa Karo UKSW angkatan 2019 yang berasal dari Sumatera Utara. JIBK Undiksha, V.12 (02): pp. 151-156, DOI: $10.23887 /$ jibk.v12i2.34016 


\section{Pendahuluan}

Mahasiwa adalah orang yang duduk di bangku perguruan tinggi. Mahasiwa yang ada di peguruan tinggi merupakan mahasiswa yang berasal dari kota tempat perguruan tinggi tersebut dan juga mahasiswa yang berasal dari luar daerah atau yang merantau.Memasuki dunia kuliah merupakan suatu perubahan besar pada hidup seseorang (Santrock, 2006; Greenberg, 1999). Universitas Kristen Satya Wacana (UKSW) adalah sebuah perguruan tinggi yang dijuluki dengan 'Indonesia Mini' (Soplanit,2008) dikarenakan mahasiswa yang menempuh pendidikan di kampus tersebut didalamnya bukan hanya berasal dari Salatiga dan sekitar Jawa Tengah saja, tetapi berasal dari segala penjuru Indonesia mulai dari Sabang dari Marauke. Sama halnya juga, suku yang didalamnya juga beragam salah satunya adalah suku Karo.

Keberanian merantau perlu dimiliki sehingga dapat membentuk pribadi yang siap menghadapi lingkungan baru, dengan banyak tantangan yang harus dihadapi (Deswita, 2009). Biasanya individu mengalami banyak perubahan di tahun pertamanya kuliah ketika memasuki perguruan tinggi. Penyesuaian diperlukan karena adanya perubahan pada kehidupan individu dikarenakan banyak mahasiswa yang belum terbiasa dengan lingkungan yang baru. Berpindah dari lingkungan yang sudah lama di kenal mulai dari subjek lahir sampai remaja ke lingkungan yang baru dan asing membuat subjek perlu menyesuaikan diri terlebih dahulu. Berhubungan dengan lingkungan yang baru sama halnya dengan orang-orang baru juga. Cara berkomunikasi di Tanah Karo, Sumatera Utara yang kental akan logat dan Bahasa Karo dan cenderung terdengar lantang, berbeda dengan lingkungan di Salatiga yang memiliki budaya yang lembut dan halus, membuat mahasiswa merasa kesusahan untuk berkomunikasi dengan lingkungan sekitar. Bukan hanya cara berkomunikasi, hal yang menjadi kebiasaan diantara dua budaya yang berbeda membuat mahasiswa Karo merasakan culture shock.

Culture shock dapat dialami oleh siapa saja yang setelah sekian lama tinggal di suatu tempat kemudian karena suatu hal dia pindah ke tempat lain yang memiliki budaya berbeda (Dayaksini dan Yuniardi, 2012). Perpindahan seseorang ke lingkungan yang baru dapat menimbulkan culture shock, maka seseorang tentu juga akan berusaha melakukan adaptasi diri terhadap budaya di lingkungan mereka. Mungkin pada awalnya mereka merasa kaget dengan budaya baru tersebut, dan mereka akan melakukan suatu tindakan untuk menghadapi culture shock yang mereka alami guna dapat menyesuaikan diri dengan lingkungan baru.Culture Shock menurut Oberg (dalam Bochner, 2003) merupakan reaksi yang dimunculkan individu ketika berada dalam lingkungan yang asing untuknya. Furnham dan Bochner (dalam Devinta,dkk (2015)) berpendapat bahwa penyebab dari gegar budaya, yaitu kehilangan tanda-tanda yang biasa dikenali seperti ekspresi wajah maupun kebiasan-kebiasaan yang sering dilakukan, perbedaan bahasa, dan krisis identitas diri.

Parillo (2008) mengemukakan bahwa salah satu hal yang mempengaruhi terjadinya culture shock adalah trait personal yang merupakan salah satu aspek dari kepribadian. Menurut Feist dan Feist (2009), Kepribadian didefinisikan sebagai pola watak yang relatif permanen dan karakter yang unik dimana keduanya memiliki konsistensi dan keunikan pada perilaku individu. Selain itu, Pendekatan teori kepribadian sering dipergunakan dalam rangka mencari solusi mengenai kesulitan-kesulitan yang bersifat personal. Allport (dalam Budiraharjo,1997), mengatakan bahwa kepribadian didefenisikan sebagai suatu organisasi dinamis dari sistem-sistem psikofisik dalam diri individu yang menentukan penyesuaian diri yang unik terhadap karakteristik perilaku dan pemikirannya.

Jung juga memberikan pendapat bahwa Kepribadian adalah keseluruhan pikiran, perasaan dan tingkah laku, kesadaran dan ketidaksadaran yang membimbing orang untuk menyesuaikan diri dengan lingkungan sosial dan fisik. Selain itu, Jung juga menyatakan bahwa kepribadian disusun oleh sejumlah sistem yang beroperasi dalam tiga tingkat kesadaran yaitu ego, kompleks, dan arsetip (Alwisol, 2009). Dalam hal ini, Jung (dalam Suryabrata, 2012) juga menggolongkan kepribadian manusia menjadi dua tipe, yaitu tipe kepribadian introvert dan extrovert. Kepribadian Introvert adalah individu yang tidak mudah membaur dan menyesuaikan diri dengan lingkungannya yang baru sedangkan Kepribadian Extrovert adalah individu yang mudah untuk berbaur dan menyesuaikan diri dengan lingkungannya yang baru.

Culture shock memiliki hubungan erat dengan Kepribadian seseorang, dapat dilihat melalui penelitian vang dilakukan oleh Chasannah (2017) vang beriudul "Perbedaan Culture Shock Ditinjau Dari Tipe 
Kepribadian Introvert Dan Ekstrovert Pada Mahasiswa Asing Di UIN Sunan Ampel Surabaya" memaparkan hasil bahwa terdapat perbedaan Culture shock pada orang yang bertipe Kepribadian Introvert dan Ekstrovert. Dalam penelitian ini disebutkan bahwa individu dengan tipe kepribadian introvert akan lebih cenderung mengalami culture shock daripada individu dengan tipe kepribadian extrovert. Begitu juga dengan penelitian yang dilakukan oleh Indrianie (2012) dengan judul "Culture Adjustment Untuk Mengatasi Culture shock Pada Mahasiswa Baru yang Berasal dari Luar Pulau Jawa Barat" yang memberikan hasil bahwa Mahasiswa dari Luar Pulau Jawa Barat memerlukan Culture Adjusment untuk mengatasi terjadinya Culture shock.

Dengan demikian penelitian ini bertujuan untuk mengetahui perbedaan Culture shock yang ditinjau dari tipe kepribadian extrovert dan introvert pada mahasiswa Karo UKSW angkatan 2019. Selain itu penelitian ini juga dapat memberikan informasi mengenai culture shock yang ditinjau dari tipe kepribadian extrovert dan introvert. Hipotesis penelitian ini adalah ada perbedaan yang signifikan antara individu tipe kepribadian extrovert \& introvert dalam menghadapi Culture shock. Individu dengan tipe Kepribadian extrovert akan cenderung memiliki tingkat culture shock yang lebih rendah, sebaliknya individu dengan tipe kepribadian introvert akan cenderung memiliki tingkat culture shock yang lebih tinggi pada mahasiswa Karo angkatan 2019 yang berasal dari Sumatera Utara.

\section{Metode}

Penelitian ini menggunakan desain penelitian uji beda untuk mengetahui ada tidaknya perbedaan yang signifikan antara individu dengan kepribadian extrovert dan introvert dalam menghadapi culture shock. Partisipan dalam penelitian ini adalah mahasiswa Karo Universitas Kristen Satya Wacana angkatan 2019 yang berasal dari Sumatera Utara dengan jumlah mahasiswa 50 orang. Teknik sampling yang digunakan adalah teknik total sampling. Teknik total sampling menurut Sugiyono (2009) adalah teknik yang penentuan sampelnya dengan mengambil seluruh anggota populasi sebagai responden atau sampel penelitian.

Instrumen dalam penelitian ini menggunakan skala pengukuran variabel culture shock menggunakan skala culture shock yang dibuat peneliti menggunakan acuan menurut Mumford (1997). Dengan 12 aitem yang menghasilkan daya diskriminasi aitem dengan rentan .329 - .700. Dan hasil reliabilitas alat ukur yaitu alpha cronbach .822 yang berarti alat ukur ini layak untuk digunakan. Sedangkan pengukuran variabel kepribadian extrovert dan introvert menggunakan skala Eyesenck Personality Questionnaire $(E P Q)$. Dengan 17 aitem yang memiliki daya diskriminasi baik dengan rentan .353 - .607. Sedangkan untuk reliabilitas alat ukur alpha cronbach .847 yang berarti alat ukur ini layak untuk digunakan. Dalam penelitian ini juga dilakukan uji asumsi yaitu uji normalitas menggunakan uji kolmogorov smirnov (KS), uji homogenitas dengan tes homogeneity of variences, kemudian dilakukan uji hipotesis menggunakan teknik Mann-Whitney U Test.

\section{Hasil dan Pembahasan}

Hasil dan pembahasan dalam penelitian ini, pada individu dengan kepribadian introvert terdapat 18 orang dengan persentase 69\% yang memiliki tingkat culture shock yang berada di kategori "Sangat Tinggi", sedangkan pada individu dengan kepribadian extrovert tidak ada yang berada pada kategori ini. 8 orang individu dengan kepribadian introvert dengan persentase $31 \%$ memiliki tingkat culture shock dalam kategori "Tinggi" sedangkan pada individu dengan kepribadian extrovert tidak ada juga dalam kategori ini. 10 orang individu dengan kepribadian extrovert dengan persentase $42 \%$ berada dalam kategori "Sedang" sedangkan pada individu dengan kepribadian introvert tidak ada dalam kategori ini. Untuk kategori "Rendah" tidak terdapat individu dengan kepribadian introvert, sedangkan pada individu dengan kepribadian extrovert terdapat 7 orang dengan persentase (29\%). Pada individu dengan kepribadian introvert tidak terdapat di dalam kategori ini, sedangkan pada individu dengan kepribadian extrovert, terdapat 7 orang dengan persentase (29\%) yang berada di kategori "Sangat Rendah" ini, yang berarti memiliki tingkat culture shock yang rendah. 
Hasil uji normalitas, dalam penelitian ini didapatkan nilai koefisien Kolmogrov-Smirnov dari variabel culture shock sebesar $\mathrm{p}=0.038(\mathrm{p}>0.05)$ dan kepribadian extrovert dan introvert sebesar $\mathrm{p}=0.011$ $(\mathrm{p}>0.05)$. Dari hasil tersebut dapat disimpulkan bahwa data dalam penelitian ini berdistribusi tidak normal sehingga uji hipotesis akan menggunakan Mann-Whitney U Test. Sedangkan hasil uji homogenitas, dengan nilai signifikansi sebesar $0.739(\mathrm{p}>0,05)$. Maka dapat disimpulkan bahwa variabel culture shock dan kepribadian extrovert dan introvert adalah homogen.

\section{Tabel 1.}

Hasil Uji Hipotesis antara skala Culture Shock dan kepribadian Extrovert dan Introvert

\begin{tabular}{|l|l|r|r|r|}
\hline & Tipe Kepribadian & N & \multicolumn{1}{|c|}{ Mean Rank } & \multicolumn{1}{c|}{ Sum of Ranks } \\
\hline Culture & Ekstrovert & 24 & 12,50 & 2,502 \\
Shock & Introvert & 26 & 37,50 & 2,531 \\
\hline & Total & 50 & & \\
\hline
\end{tabular}

Tabel 2.

Mann-Whitney U Test

Test Statistics ${ }^{\mathrm{a}}$

\begin{tabular}{|l|r|}
\hline & \multicolumn{2}{|c|}{ Hasil } \\
\hline Mann-Whitney U &, 000 \\
Wilcoxon W & 300,000 \\
Z & $-6,081$ \\
Asymp. Sig. (2-tailed) &, 000 \\
\hline
\end{tabular}

a. Grouping Variable: Tipe Kepribadian

Hasil uji hipotesis dengan menggunakan Mann-Whitney U Test, mendapatkan hasil sig. (2-tailed) = $0,000$ ( $p>0,05)$. Hasil tersebut menunjukkan ada perbedaan yang signifikan antara individu tipe kepribadian extrovert dan introvert dalam menghadapi culture shock. Berdasarkan uji yang telah dilakukan, pada table Ranks diperoleh Mean Rank tingkat culture shock dengan tipe kepribadian introvert sebesar 37,50, dimana lebih tinggi dari Mean Rank tingkat culture shock dengan tipe kepribadian extrovert sebesar 12,50. Hal ini menunjukkan bahwa tingkat culture shock yang dimiliki individu dengan tipe kepribadian introvert lebih tinggi dari individu dengan tipe kepribadian extrovert. Hasil ini sejalan dengan penelitian yang dilakukan oleh Chasannah (2017) yang menunjukkan bahwa terdapat perbedaan yang signifikan antara culture shock dan kepribadian extrovert dan introvert dalam menghadapi culture shock.

Furhan \& Bochber (1986) mengatakan bahwa jika seseorang sulit menyesuaikan diri, maka gejala culture shock akan muncul, bahkan dalam kurun waktu yang lama. Hal ini sejalan dengan penelitian yang dilakukan terhadap mahasiswa yang merantau untuk melanjutkan pendidikan sehingga harus meninggalkan keluarga dan lingkungan asalnya. Di lingkungan yang baru, individu dipaksa untuk menyesuaikan diri dengan lingkungan sekitarnya dan bisa menempatkan diri agar bisa menjadi bagian dari lingkungan tersebut. Oleh karena itu, trait atau kepribadian individu sangat mempengaruhi penyesuaian diri yang akan dilaksanakan, tipe kepribadian extrovert adalah individu yang memiliki kemampuan bersosialisasi yang baik, sehingga jika diberikan lingkungan yang baru, akan cukup mudah baginya menyesuaikan diri. Selain itu, individu dengan kepribadian extrovert adalah orang yang dapat menempatkan dirinya dengan baik dan mudah bergaul dengan lingkungan sekitarnya karena fikiran, tindakan dan perasaannya dipengaruhi oleh dunia luarnya (objektif) sehingga tingkat culture shock yang akan dihadapi akan rendah. 


\section{Simpulan}

Berdasarkan hasil penelitian yang dilakukan dapat disimpulkan bahwa ada perbedaan yang signifikan antara individu dengan tipe kepribadian extrovert dan introvert dalam menghadapi culture shock. Individu dengan tipe kepribadian introvert akan memiliki tingkat culture shock yang lebih tinggi, sebaliknya individu dengan tipe kepribadian extrovert akan cenderung memiliki tinkgat culture shock yang lebih rendah pada mahasiswa Karo UKSW angkatan 2019 yang berasal dari Sumatera Utara.

\section{Ucapan Terimakasih}

Puji syukur saya panjatkan kepada Tuhan Yesus atas izinnya saya boleh menyelesaikan tugas dan tanggung jawab ini. Terima kasih kepada kedua orang tua saya, Dosen pembimbing di Universitas Kristen Satya Wacana, Dosen Universitas Pendidikan Ganesha dan pada rekan - rekan mahasiswa yang turut ikut serta dalam penyelesaian penelitian ini. Kepada anggota Ikatan Generasi Muda Karo khusunya angkatan 2019 terima kasih untuk bantuannya dalam menyelesaikan penelitian ini. Semoga ilmu yang sudah saya dapatkan dan saya pelajari dapat bermanfaat dan berguna dikemudian hari.

\section{Referensi}

Alwisol.(2009). Psikologi Kepribadian. Malang: UMM Press

Bochner, S. (2003). Culture Shock Due to Contact With Unfamiliar Culture. Online Reading in Psychology and Culture Vol.1 No.4 .7-9

Budiraharjo, P. (editor). (1997). Mengenal Teori Kepribadian Mutakhir. Yogyakarta : Kanisius

Chasannah, U. (2017). Perbedaan Culture Shock Ditinjau Dari Tipe Kepribadian Introvert Dan Ekstrovert Pada Mahasiswa Asing Di UIN Sunan Ampel Surabaya. Skripsi Fakultas Psikologi Universitas Islam Negeri Sunan Ampel Surabaya

Dayaknisi, T.(2012). Psikologi lintas budaya. Malang : UMM Press

Devinta, Marshellena, Hidayah, N. \& Hendrastomo, G. (2015). Fenomena Culture Shock (Gegar Budaya) Pada Mahasiswa Perantauan Di Yogyakarta. Jumal Pendidikan Sosiologi.Vol (1). 3-15

Feist, J., \& Feist, J.G. (2009). Theories of personality, seventh edition. New York: The McGraw-Hill Companies.

Furham, A. \& Bochner, S. (1970). Culture shock, psychological reaction to unfamiliar environment, New York : Cambrige.

Santrock. (2006). Life Span Development: Perkembangan Masa Hidup. Jakarta: Erlangga

Soplanit, M. E. (2008). Perbedaan Penyesuaian Diri Mahasiswa Baru Yang Tinggal Di Asrama Ditinjau Dari Jenis Kelamin Dan Daerah Asal. Skripsi. Fakultas Psikologi Universitas Kristen Satya Wacana.

Sugiyono. (2011). Metode Penelitian Kuantitatif Kualitatif dan R\&D. Alfabeta: Bandung

Parillo, V. N. (2008). Encyclopedia of Social Problems. Thousand Oaks : SAGE Publication 
Conflict of Interest Disclosu res:

The authors declare that they have no significant competing financial, professional or personal interests that might have influenced the performance or presentation of the work described in this manuscript.

Copyrights Holder: Yessy Sepgina Br Manik ${ }^{1 *}$, Berta Esti Ari Prasetya $^{2}, 2021$

First Publication Right: JIBK Undiksha https://doi.org/10.23887/jibk.v12i2.34016

O pen Access Article | CC-BY Creative Com mons Attribution 4.0 International License.

Word Count: 